\title{
A Rustic Opinion on Translation Methods of Humorous Language in English
}

\author{
Yongqiang Xia \\ Sichuan University of Arts and Science, Dazhou, 635000, China
}

\begin{abstract}
Keywords: English Humors, Desperate Housewives, Translation of Figures of Speech, Free Transltion
\end{abstract}

\begin{abstract}
Humorous language is the most important part of the English language, and also it reflects the features of English language. It is essential to consider the divisities on national culture, character, the way of thinking and living background between China and England when we try to translate these humorous language to chinese. That is the reason why we think the translation is part of difficult. This paper selects the translation of figures of speech, and we attempt to investigate the application of figures of speech on chinese translation through dialogues of "Desperate Housewives".
\end{abstract}

\section{Introduction}

"Desperate Housewives" is one hot American drama of ABC which begins from 2004, and it is divided into eight quarters for eight years. During these years, this drama become more and more popular not only in American market but also in China market. This play destribes the life of a group of white-collar female of America's metropolis, and it reflects the reality of America's society from the pespective of American female, and also it applies plentiful female language and humorous language. From the point of rhetoric theory, these language application has nature of ci-poetry, and the applications of figures of speech also embody a page of changeable and connotative, such as metaphor, pun and irony. These lines enrich the personality of those characters and also enhance the attractiveness of the plots ${ }^{[1]}$.

\section{The rhetoric of language}

Rhetoric has played the most important role in the language development which has a long history and insights a lot. In weatern world, many famous philosophers, such as Aristotle defines the rhetoric as "the art of speech". In "The introduction on the rhetoric", it refer to "the rhetoric is the way of adjustment on words and expressions which could enhance effectiveness and regularity in the process of transmission". Then in this paper, it could represent its skills, methods and regularity only by the spectific language contexts and style. So, people need to focus on the denarcation of functions and backgrounds during the process of investigation ${ }^{[2]}$.

\section{The Example Analysis on rhetorical translation of humorous language in 'Desperate Housewives'}

In the practical translation of humorous language, it is equal important to consider the language skills and other non-linguistic factors. Non-linguistic factors are also called cultural factors, it is multilayer and multi-angle and it refers to culture,characters ideology and religious belief. 'Desperate Housewives' destribes American life typically, and it needs a high translation standard to translate those humorous dialogues so that Chinese people could understand. The following are example analysis on translation skills of humporous language of this play from different rhetorical devices.

\section{Metaphor}

Metaphor is a common figure of spech in humorous language, it requires to connect two different and irrelevant things and compare them. By this way, one thing could indicate features of the other things. Metaphor and simalar are relativa, both could express a way of looking objectively. The 
application of metaphor in language expression perhaps contructs a unexpected effects, and also humorous atmosphere.

Take dialogue of 'Desperate Housewives' for example:

Example 1:Renee:Oh,Doug screw up a lot of things,but his apologies are always the 4th of July.

Translation:Renee:道格净做坏事, 但是他的道兼总能像国庆节一样让人开心激动。

This is the application of free translation, for that there are no words such as "make s.b happy", it is implication. But the texts could express the implications so that it make texts complete and make more humorous. As for '4th of July', it is a kind of metaphor, this is the national day of American, so Americans are willing to use ' 4 th of July' to indicate there happiness.

Example 2:John:I can see the family resemblance.

Calos:She is my niece.

John:It must've been a windy day when the apple fell off that tree.

Translation:John:你们长得还挺像。

Calos:她是我侄女。

John:那一定是那天大风把你从树上吹下来的。

The background is the illegal love affairs between Hohn and Gaby. And John and Calos are the rivals. John regards Anna as Gaby's niece and tells she is beautiful when John met Calos in restaurant. However in fact, Anna is niece of Calos, and John use metaphor to compare Anna to the falling apple by wind, the indication is that Anna is unlike Calos, Calos is too ugly. These humorous language not only make a comic effect, but also keep back literal translation in dialogue.

\section{Pun}

The pun comes from Shakespeare's literary era of England, but it is different between modern and the before that there are more humorous and popular instead of elegance. Pun could also be regarded as a figure of speech which have same voice and meaning, its nature is the metapher and similar under some specific conditions.

In English language, there are two different pun that same words and homonym. The same words are simliar pronunciation and spelling with different meanings. For example, "After several years of hard work,we still can't see any change in his purse", in this sentence,change is the pun, it can be correct both with its two meanings. And the real intention is to express other meaning through one meaning, and the other meaning is the real purpose.

Homonym means words with same pronunciation but different meanings. For example, "I'm like a bicycle can't stand alone cause it's two-tired", in this sentence , 'two tired' and 'too tired' has same prounciation, its meaings are that “我就像一辆自行车无法单独站立因为我的双脚现在太累了(两 个轮子无法独立站立) '. This way of pun is humorous and also smart.

Take dialogue of 'Desperate Housewives' for example:

Example 1:Bree:Well,it's just tha she's so'*cheap.She's beneath you..

Karl:Not yet,but she will be.

Translation:Bree:她太不靠谱了, 完全在你之下。

$\mathrm{Karl}$ :还没在我身下, 不过快了。

In this dialogue, “beneath” is pun. On one side, it means”o配不上”, or"在……之下”. This is a way of literal translation, could also be tranlated to “配不上你 (或在你身下)”. In drama, Karl shoot back to Breeby this way of pun with humorous language and good effects. The pun could express figures's mental activities, and more important is usage of Chinese to express original intentions which could reserve irony for a hundred percent.

Example 2:Lynette:God,you know about the twins.

Calos:Well,I mean,yeah.I have eyes.

Lynette:OK,first of all,this was not planned.

Translation:Lynette:上帝! 你已经知道双胞胎的事情了?

Calos:当然知道了, 我有长眼睛。

Lynette:首先声明, 这完全是计划之外的事。 
There are two pun in dialogue above. Lynette thinks Calos has known the things of pregnancy, so 'twins' in her words means her own twins. But in fact, Calos do not know this thing, so 'twins' in his words means Lynette's breast. And Lynete explains pregnancy is not her plan ,just accident. This 'plan' is just plan, but Calos understand is as planned mistakenly. He think Lynette is telling her big breast is not breast shaping. During this process, there are many humorous things in their dialogue, and meanwhile, Chinese translation also use the pun to express comic effects.

\section{Irony}

Irony always make humorous in language, it make humorous by sarcasm others. Just as its name implies, irony expresses the opposite meaning with its literal meaning, is one figure of speech by expressing contrary. So, irony could be more impressive.

For example: Cleaner said to Bree "Well,if you finish your magazine, there is a bible in the nightstand"

Translation:等你看完了那本杂志, 床头柜上还有本圣经。

This sentence belongs to situational irony in English humorous language. Situational irony requires coherence between situation and language. And wirter think that there are some culture element in this sentence, for that auidence could not find laughing points even we translate it to Chinese. In fact, cleaner considers Bree's husband as a good man, but Bree cheats to her husband with other people, cleaner considers Bree as a shameless person. In western culture, people have beliefs in Christian, bible represents education and influence on people's ideology and morality. In this sentence, the cleaner satirizes Bree's behaviour and indicate Bree need to read bible to reflect herself. The effect of irony is appropriate, both humorous and irony. So we need to reserve its specific situations and contexts during Chinese translation, and this kind of irony need auidence to have a deep understand of American culture.

\section{Hyperbole}

Hyperbole is commin in language humor. It could indicate figures's emotions strongly and deepen humorous and irony if we connect American local slangculture with hyperbole.

Example:Mike:There you are.Your son's been waiting four million years.

Translaiton:你可终于回来了，看看，你儿子已经等你半年了。

This sentence has a deep hyperbole colouring, that “four million years"means your son's been waiting four million years. If we just translate it to 'two million years', there are nothing humorous for Chinese auidence, if we change it to half year, it is more popular, especially for the northerners.

Absolutely, we need to consider two elements in hyperbole translation, at first, it should obey the fact and could not violate normal logic, it is just a way of figure of speech of exaggerate thing's features, not change facts. So, we need to pay attention to this principle. On the other side, hyperbole need to be creative, American's slang humor is not suitable for Chinese auidence. So we need to consider local humor to make a translation, those words which could express exaggerated indication are better. Therefore, a good translation of figure of speech should achieve a sense of beauty and skilled consideration.

\section{Personification}

Personification has its specific features, and it is because this specific features that could deepen infections of language. Personification should trigger auidence's laughing point by its vividness and picturesqueness.

Example 1:Calos:You'd rather scrub the toilets than teach your daughter?

Gaby:Well,at least the toilet won't talk back.

Translation:Calos:你宁愿刷马桶也不愿意教你的女儿吗?

Gaby:至少马桶不会和我顶嘴。

In this dialogue, Gaby would not like to tutor her daughter and want to hire a home tutor. Calos asks Gaby that she would like to scrub the toilet rather than teach her daughter, and Gaby's answer is funny, she personates the toilet, toilet is beteer than daughter, at least toilet won't talk back. This sentence is a good example of personification, and a bit of hyperbole, so we just use literal translation, and this way of performance result is the best ${ }^{[3]}$. 


\section{Summary}

On the basis of the argument on rhetoric translation of "Desperate Housewives", we can see deep-seated skills about rhetoric translation in English-Chinese translation. Not difficult to find that all the figures of speech have applied metaphor, free translation and such expressive methods, which indicates the inevitability of logical and cultural transmission. This method is to balance and remedy the culture between American and China, and also to strengthen expression and infectivity of language in different cultures. Therefore, this paper hope to provide assistance to people to understand the translation of figures of speech in English humor, then enhance help Chinese to conprehend western culture and connisseurship of filmographies.

\section{References}

[1] Fenglai Lin, Discussion on difficulties and strategies of humor English-Chinese Translaion. Foreign Language Institute of Fujian Province, 2008,(12): 111=113.

[2] Shanhui Jiang, The common techniques of expression and translation strategy of humor English. The Jornal of Zhangqiu Vocational Techinical Institute,2014,(3):89-90.

[3] Jianhua Liu, The Research on Rhetorical Lnaguage and Translation of 'Desperate Housewives'. Hebei University, 2011. 8-21. 